\title{
Austrian economics
}

\section{Recent work}

\author{
Mario J. Rizzo
}

\section{Introduction}

In the past 25 years, a large amount of new research in Austrian economics has developed and expanded the basic themes that are central to its unique identity (O'Driscoll and Rizzo, 1996). These highly interrelated themes are (1) the subjective, yet socially embedded, quality of human decision-making; (2) the individual's perception of the passage of time ("real time"); (3) the radical uncertainty of expectations; (4) the decentralization of explicit and tacit knowledge in society; (5) the dynamic market processes generated by individual action, especially entrepreneurship; (6) the function of the price system in transmitting knowledge; (7) the supplementary role of cultural norms and other cultural products ("institutions") in conveying knowledge; and (8) the spontaneous - that is, not centrally directed - evolution of social institutions. The specific ways in which these themes have recently manifested themselves is the subject of this article.

Since our task is to discuss the developments in Austrian economics primarily since the last New Palgrave Dictionary of Economics entry in 1987 we shall not review the work of the many "classic" Austrian authors. In addition, since our concerns are the substantive developments in the field, we omit many valuable contributions in the history of economic thought and in methodology.

\section{Macroeconomics and monetary theory}

There have been many advances in Austrian macroeconomics. These include new work on business cycle theory and on alternative monetary institutions.

Each of these areas can be looked at from the general perspective of treating time, money and their related institutions seriously (Horwitz, 2000). Time is the medium of all action. Decisions are taken in time to produce consequences in the future. Taking time seriously means also taking the uncertainty that characterizes these decisions seriously. This applies to savings-investment choices, production plans and the time structure of capital goods. In an Austrian (and Keynesian) perspective the pervasive uncertainty of the future 
makes money necessary. Thus, as time is the medium of all action, money is the medium of all exchange. All goods markets are accordingly affected by the supply and demand for money and the nature of monetary institutions.

The Austrian Business Cycle Theory (ABCT) received a major systemization and refinement in the work of Roger Garrison, culminating in his book, Time and Money: The Macroeconomics of Capital Structure (2001). The previous work in the subject was scattered in many articles by Friedrich Hayek and in the work of Ludwig von Mises. It was also very imperfectly linked to the brilliant, but underrated, work by Ludwig Lachmann, Capital and Its Structure (1956). Garrison corrects these deficiencies and adds coherence to $\mathrm{ABCT}$ which had previously been unknown. In a sense, Garrison has done for ABCT what John Hicks and Alvin Hansen did for Keynes' macroeconomics, except that the Garrison's work is an accurate rendition of Hayek, Mises and Lachmann.

The subtitle of Garrison's book, "The Macroeconomics of Capital Structure," expresses the important claim that Austrian macroeconomics cannot adequately be appreciated without understanding that "investment" is not a homogeneous decision. This insight is developed at length by Peter Lewin in Capital in Disequilibrium: The Role of Capital in a Changing World (1999), the most important work in Austrian capital theory in many decades (see also Endres and Harper, 2008). The ABCT focuses on the inappropriateness of the capital structure (malinvestment) generated by artificially low real interest rates (that is, interest rates that are lower than the real supply of savings would allow). Thus, the term overinvestment is, by itself, a misleading characterization of the $\mathrm{ABCT}$ process. While excessively low interest rates do increase the level of investment relative to its previous position, they do so in a biased way - those stages of production further from consumption are affected to a greater extent.

However, as Garrison's recent work (2004) has shown, there are even more widespread distortions in the production structure generated by artificially low interest rates. These include initial "overconsumption" as the result of reduced savings and of increased incomes on the part of factors of production. Increased investment in close temporal proximity to the overconsumption is labeled the "derived demand effect." This is in addition to the "discount effect," described above, which increases the profitability of new investment distant from consumption. These two contrary effects come at the expense of intermediate stages of production as well as reduced maintenance of existing capital at all stages. They may even result from the utilization of unused resources during periods of less than full employment. These effects show that the ABCT is a type of "coordinationist macroeconomics" insofar as it describes the discoordination of various sectors of the economy, and is not simply a micro, choice-theoretic approach to macroeconomics (Wagner, 2005).

Accordingly, in this Austrian view recessions are characterized not simply by low levels of aggregate economic activity but also by the misdirection of 
resources caused by previous boom-induced malinvestments. These systematic sectoral imbalances - too much investment in interest-sensitive areas of economic activity - must be corrected as recovery proceeds.

The Austrian theory, however, is not a complete theory of the business cycle. It accounts mainly for the process leading to and including the cycle's upper turning point. It is a theory of the crisis. How long the resulting recession lasts is not predicted by the theory or even, strictly speaking, by the degree to which resources were misallocated. The length of the recession will depend, for example, on those factors affecting the mobility of resources.

None of this implies that Hayek, Garrison or Horwitz are insensitive to the problems that would be induced by an aggregate increase in the demand to hold money (a fall in income velocity), which can accompany recessions. This "secondary deflation" should be avoided by a concomitant increase in the supply of money by the relevant monetary institutions. Horwitz (2000) is the first to integrate Austrian macroeconomics with monetary disequilibrium theory to analyze deflationary processes. Nevertheless, recessions are not primarily deflationary phenomena (or at least need not be), but occasions for correction of the misdirection of resources. Some Austrians, however, argue that increases in the demand for money have significant negative consequences only in the presence of legal restraints on price flexibility (Salerno, 2003).

One of the most important possible obstacles to recovery from recessions may be in the behavior of "big players." These are agents whose discretionary behavior, insulated from the normal discipline of profit and loss, can significantly affect the course of economic effects (Koppl and Mramor, 2003; Koppl, 2002; Koppl and Yeager, 1996). Thus, discretionary behavior on the part of monetary authorities (in the United States, the Fed), fiscal policy makers (Congress or the executive), or even in some cases private monopolists, can increase uncertainty faced by most economic agents ("small players"). They will have to pay more attention to trying to guess the perhaps idiosyncratic behavior of the big players. Economic variables will become contaminated with big-player influence. It will become more difficult to extract knowledge of fundamentals from actual market prices. And thus entrepreneurs will find it harder to determine where resources should be withdrawn and where they should be added in a way that is sustainable in the medium to long term.

An important variant of the ABCT in Risk and Business Cycles: New and Old Austrian Perspectives (1998), developed by Tyler Cowen, focuses on the integration of business cycle theory with developments in modern finance. The main sense in which this can be called a variant of ABCT is that changes in the riskiness of investment decisions are linked to the "old Austrian" concern with the degree of futurity or roundaboutness in investments. For example, in Cowen's analysis, an increase in the acceptable level of risk will encourage undertaking more longer-term investments (as well as, of course, investments of any given length with more uncertain yields). These can be both investments in durable capital goods (that is, investments with a continuous flow of payoffs over a long period of time) and investments with a long period of 
gestation before the ultimate output is produced. Cowen associates less risky ("safe") investments with consumption and shorter-term investments.

Cowen's analysis is more general than the traditional ABCT because it allows many factors besides a fall in real interest rates to generate a lengthening of the capital structure. These include exogenous risk-preference shifts, increases in savings, easing financial constraints, and reductions in uncertainty (so as to reduce "waiting" for acceptable investment opportunities). Any of these changes can generate an increase in the riskiness of investment. None of these changes must necessarily cause a cyclical boom and bust, but they might do so.

Horwitz (2000) shows that the traditional business cycle concerns of Austrian macroeconomics quite naturally lead into comparative institutional analysis. Therefore, the obvious question is: what kind of institutional framework is necessary or conducive to avoiding the distortionary effects of inflation and deflation? Austrians have been critical of both discretionary central banking policies and rigid monetarist rules. Some have favored free banking while others have favoured a 100 percent (usually gold) reserve requirement and hence have opposed fractional reserve banking.

The free banking school, represented by Selgin and White (1994), Horwitz (2000), Dowd (1996) and Sechrest (1993), emphasizes the importance of adjusting to changes in the demand to hold money (income velocity). For prices in particular markets to do their work appropriately in transmitting knowledge and allocating resources they must be free of the distortions induced by inflation and monetarily induced deflation. Free banking advocates argue that bank profit maximization, under sound institutional constraints, will lead banks to expand or contract deposits or currency pari passu with changes in the demand for money. Banks will receive signals about the demand for (their) money as their reserves expand or contract. When reserves expand, the demand to hold is increasing, and vice versa. Profit maximization leads banks to increase the supply of money when reserves expand beyond their desired levels. Thus, no explicit monetary policy is needed to avoid unwarranted expansion or contraction on the "money market," just as on commodity markets no deliberate industrial policy is needed to avoid unwarranted expansion or contraction of resources in different areas.

The advocates of 100 percent reserve money follow the work of Murray N. Rothbard (1983). These include Block (1988), Hoppe (1994) and Huerta de Soto (1995). They argue that free banking - to the extent that it is fractional reserve banking - is ethically suspect. Regardless of the merits of this argument, our concern here is solely with economics. They further argue that fractional reserve banks are inherently inflationary because any creation of fiduciary media beyond an increase in specie will generate a business cycle. (The word "inflationary" is being used here either as a definition - an increase in money not covered by an increase in specie - or as an intellectual placecard to suggest the generation of a cycle.) Critiques are offered in Horwitz (2000) and in Selgin and White (1994). 


\section{Entrepreneurship}

The theory of entrepreneurship has been a subject of great importance in Austrian economics since the publication of Israel Kirzner's Competition and Entrepreneurship (1973). One could argue, of course, that this was implicit in the prior works of Ludwig von Mises and Friedrich Hayek. Nevertheless, there is an important difference between implicit and explicit ideas. Over a long period of time, Kirzner refined his theory of entrepreneurial discovery or alertness in many books.

Kirzner's approach is predominantly cognitive. There are roots of this cognitive approach in the early work of von Mises (Ebeling, 2007). However, quite curiously in this time of the resurgence of psychology and economics, it is a cognitive theory without explicit cognitive foundations. Kirzner is interested in the market implications of the fact that there is entrepreneurial alertness. He is not interested, beyond some very general observations, in the causal factors that give rise to or are conducive to alertness.

Alertness, or equivalently, entrepreneurial discovery, is hard to define. It is a creative, spontaneous and to a certain extent idiosyncratic, mental act that goes beyond the mere apprehension of objective data. First, while it usually begins with objective data, it critically involves drawing connections with other data when those connections are not obvious or even the result of complex computations. Second, true discoveries are not the result of deliberate acts of search. They cannot reliably be attained by the simple deployment of resources. Something more is necessary. This is not to suggest, however, that they must be viewed as random shocks to the economic system. They can be cultivated and prepared for by deliberate decisions, but they cannot be mechanically produced by them. We might say that while deliberate search is not a sufficient condition for discovery, it is necessary. Even better, eschewing the excessively constraining categories of necessity and sufficiency, we might say that the serendipity of discovery favors the searching mind (Holcombe, 2007; Shane, 2000). Finally, it is likely that many individuals can be exposed to the same data and yet not make the discoveries that the alert individual does.

In a market context, entrepreneurial cognition is the discovery of profit opportunities. In Kirzner's perspective, this is based on noticing price inconsistencies, whether at a point in time or across time. Hence this is an arbitrage theory of profit. How well this conception of entrepreneurship takes uncertainty into account is a matter of some dispute (Kirzner, 1982). In the theory advanced by Young Back Choi (1993, 1999), however, uncertainty is more explicitly considered. In this perspective, related to Schumpeter's classic analysis (1934), entrepreneurs break through the conventional way of looking at the world. These conventions were originally adopted to reduce uncertainty. But as time goes on the world changes and they become less and less effective. Profit opportunities accumulate. Entrepreneurs adopt new paradigms that enable them to see the new profit opportunities that conventionalists cannot. 
To the extent that entrepreneurial discovery is unconnected to any cognitive or psychological basis, it functions as a deus ex machina of the market process. It drives the processes that occur in response to errors and disequilibria. Ultimately, it is defined by what it does. This approach has been criticized because it presupposes empirical psychological processes that are not necessarily present in all circumstances (Jakee and Spong, 2003). Can we say anything systematic about the factors that, on an individual or social level, are conducive to discovery? If we can, we might begin to understand more precisely what it is, when it is successful and when it is not.

In the first unified analysis of the factors affecting entrepreneurship, David Harper focuses on the presence of a sense of personal agency as the primary factor. "It comprises two cognitive elements - beliefs in the locus of control (or contingency expectations) and beliefs in self-efficacy (or competence expectations)" (Harper, 2003, p. 14). This means that the entrepreneurial agent believes that in a particular context results are contingent upon actions as opposed to luck or nature, and that he himself possesses the personal capabilities to effect these actions and thus to produce the overall results. Individual characteristics also interact with situations to make the development of a discovery propensity more likely. Harper goes on to show the ways in which economic, political and cultural institutions mediate the individual factors.

In most Austrian treatments entrepreneurial discovery is important because it drives the market process. Nevertheless, in path-breaking work Frederic Sautet (2000) shows that there are multiple levels of entrepreneurship. In the simple case, the entrepreneur is herself alert to profit opportunities outside of the firm. In the more complex case, the entrepreneur must face the fact that she often doesn't know what her employees know. They are often closer to the local facts and may have a superior insight in some respects about profit opportunities in the firm (from restructuring) as well as outside of the firm. Thus, the entrepreneur in a "complex firm" will seek to structure the firm with abstract or loose rules - some relating to compensation schemes - that encourage employees to make discoveries and communicate those appropriately. The firm itself can be a locus of entrepreneurship. In related work, Harper (2008b) suggests that a team of individuals, either inside or outside firms, might also constitute an entrepreneurial unit.

Randall Holcombe (2007) utilizes an idea of entrepreneurship beyond pure cognitive alertness, which includes, as well, acting upon the perception of novel opportunities. In this view, the entrepreneur can never be certain that she has correctly perceived a profit opportunity until she acts and assesses the consequences.

Some Austrians have not followed Kirzner in their analysis of entrepreneurship. For example, Joseph Salerno (1993) rejects the characterization of alertness as the essence of entrepreneurship. He sees resource ownership as a necessary feature of entrepreneurial activity (Salerno, 2008). Along similar lines, K. Foss et al. (2007, see also P. Klein, 2008; K. Foss and N. Foss, 2007) have weaved together aspects of Knight's uncertainty theory (1971) and 
Austrian heterogeneous capital theory (Lachmann, 1956) to create a theory of entrepreneurial judgment. This theory makes entrepreneurship inseparable from asset ownership. The entrepreneur's judgment is about the control of heterogeneous capital assets under conditions of radical uncertainty. These authors have applied their theory to understanding the internal operation of the firm.

\section{Market processes and economic institutions}

The entrepreneurial function is closely related to market processes and economic institutions. These interrelations are both complex and important. It will help to somewhat artificially separate them for our consideration.

A. The Austrian approach to market processes is distinctive in a number of respects (Wagner, 2007, 2010). It is sometimes described as a genetic-causal theory (Cowan and Rizzo, 1996). First, markets are in process and not continually in equilibrium. Thus, most Austrians do not take interpersonal equilibria of any kind simply as given or as consequences of an axiom of rationality. (An exception is Salerno (1994), who considers momentary market-clearing equilibrium as an implication of rationality.) Lack of alertness can be responsible for economic errors and inconsistencies (or lack of interpersonal coordination). The market process consists of those entrepreneurial responses to error. Kirzner and others take the view that market processes are generally coordinating: that is, that they generally correct market errors. Austrians accept this as an empirical generalization. The extent to which the empirical generalization can be traced to an a priori discovery tendency is a subject of debate. Kirzner appears to accept this view because he sees the tendency to discover as equivalent to, or tightly connected to, the tendency toward greater coordination (Kirzner, 1997). Rizzo, however, rejects this equivalence (Rizzo, 1996). Other authors have also expressed similar, though not identical, criticisms (D. Klein and Briggeman, 2009; D. Klein, 1997). The neoclassical view that equilibrium is an implication of rationality should not, in this author's opinion, be replaced with the view that a tendency to equilibrium is the implication of purposefulness. The former has empirical implications while the latter is not clearly defined, unless it is meant as the positive heuristic of an empirical research program (Rizzo, 1982).

Second, market processes are not instantaneous but take time. In the passage of time ("real time"), knowledge changes and unpredictable events occur (O'Driscoll and Rizzo, 1996). What were data at the start of a process may change because the process of "equilibration" occurs in real time. Real time cannot elapse without knowledge changing.

Third, market processes take place in the context of radical uncertainty. This is to be distinguished from risk, in which all of the possibilities are known with objective probabilities. However, radical uncertainty is not simply a condition where the assigned probabilities are not objective, but one in which not all of the possibilities are known beforehand. (Still further complications 
ensue because sometimes individuals know that they don't know the possibilities and sometimes they do not.)

This leads to the fourth feature of market processes: they are relatively indeterminate. If market processes - in the form of entrepreneurial discovery - cannot be predicted, then the economist cannot know at the beginning where they will lead. In the process of adjusting to change, new "data" will be discovered (Rizzo, 1990, 2000). How far to take this point about the indeterminacy of market processes is subject to debate and may, in part, depend on definitional issues (Holcombe, 2007). Some have argued that Kirzner, in particular, has incorrectly downplayed this indeterminacy (Jakee and Spong, 2003).

This is not to rule out the use of constructs in which equilibria are reached as heuristic devices when appropriate (Holcombe, 2007). However, since they are simply heuristic devices they can be thrown out when circumstances do not warrant such "static" dynamics.

The fifth, and final, feature of market processes is the communication of decentralized or scattered knowledge. Markets enable individuals to act on more knowledge than they can ever hope to possess explicitly. They can do this through entrepreneurially produced market prices and through nonprice manifestations of market behavior. As Hayek showed, the man on the spot may be directly aware of certain economically relevant conditions. If he acts by taking advantage of this knowledge in profitably buying or selling he will ensure that market prices communicate what he knows (Hayek, 1948; Kirzner, 1992a).

Prices are not the only communicators of knowledge in markets. Capital goods also embody knowledge. First, the particular use and combination of capital goods can, under nondistortionary conditions, convey knowledge about efficient resource allocation and possible profit opportunities (Lachmann, 1956). Second, even the physical design of capital goods can convey accumulated knowledge about successful production techniques (Baetjer, 2000).

In general, the communication of knowledge in market settings depends not only on catallactic phenomena but also crucially on the appropriate "institutional" context. This includes legal and cultural products (Harper, 2003). In the latter category David Harper (2008a, 2010) has drawn attention to the role of numerical cognition - a product of both unique human biology and cultural development - in facilitating economic calculation. The development of conventionalized systems of number sequences and techniques of counting reduces transaction costs, and helps agents to make plans, compute values, scarcities, notice arbitrage opportunities and ascertain the economically relevant aspects of capital goods.

B. Entrepreneurship does not simply operate within a familiar institutional structure like the market. It can also operate within structures like those involving social ties, philanthropy, nonprofit organizations and so forth (Boettke and Coyne, 2009). There is also "political entrepreneurship" within a given constitutional or governance structure, which seeks to create coalitions 
to effect specific legislation or transfers of wealth ("rent-seeking"). These nonmarket structures determine the precise form that entrepreneurship takes. The common differentiating factor that separates the entrepreneurship of the market process from these other forms of entrepreneurship is the absence of the discipline of monetary profit and loss in the latter cases. Although money may change hands as a result of these forms of entrepreneurial activity, their outputs are not valued according to market prices. Whether effective feedback mechanisms exist in these contexts is an open question (Boettke and Coyne, 2009).

Some Austrians, however, have emphasized that nonmarket institutions can indeed provide feedback to entrepreneurs and can generate a social learning or knowledge-communication process similar to market prices and profit-loss signals (Chamlee-Wright, 2008; Chamlee-Wright and Myers, 2008; Lewis and Chamlee-Wright, 2008). In particular, reputation and status are forms of "social capital" that convey information. Under conditions of competition and effective monitoring of standards, knowledge can be transmitted far beyond networks of individuals in direct communication with each other.

An important example of the communication of knowledge in a nonmarket context can be found in the scientific community (McQuade and Butos, 2003). We discuss this below in the section on spontaneous orders.

Entrepreneurship can also shape or create institutions. Rules of behavior that surround and define markets, constitutional systems, social and cultural systems arise out of the previous framework of rules, whether it was de facto or de jure. (In fact, the distinction between de facto and de jure may not be all that important for the economics of institutions, aside from the possible issue of transaction costs.) There is path dependency in the development of institutions (Boettke et al. 2008). Those that develop as "indigenously introduced endogenous institutions" are closely related to the informal practices and expectations of people, which in turn are grounded in local knowledge and values. Other institutions may be indigenously introduced but are exogenous in the sense that they are imposed by some formal authority, and do not gradually evolve from the informal traditions of a people. There is a risk that these institutions will not "stick" because of conflict between the institution and the underlying norms. Externally (or foreign-) introduced exogenous institutions exhibit the greatest probability of not succeeding because of the greater likelihood of conflict with underlying norms and expectations. Boettke et al. (2008) refer to this analysis as an example of the "regression theorem" first propounded by Ludwig von Mises (1953) in his analysis of the evolution of money.

Some of the evolution of framework institutions may simply be the undesigned outcome of individual behavior that is not necessarily entrepreneurial, as when people follow each other in making a path through the snow (Kirzner, 1992b). In other cases, there may be alertness to possibilities of gain for the relevant acting parties in altering the political or social frameworks. Plausibly, the creation of the US Constitution was one such case. 
Institutions exist at many levels. Perhaps the most basic are those that involve informal institutions like customs, traditions, norms and religion (Williamson, 2000). These take the longest time to change. They may also determine the standards by which lower-level institutions and behavior within them are evaluated. A new political system is good or bad depending on the (more basic) norm structure in place.

\section{Spontaneous orders}

Our discussion of entrepreneurship and of institutions leads naturally into a discussion of spontaneous order, an idea very closely associated with Austrian economics. Unfortunately, the term "spontaneous order" is opaque. Somewhat more descriptive is the expression made famous by F.A. Hayek, "the results of human action but not of human design" (Hayek, 1967), and even more descriptive is the idea of unintended social order produced by individually purposeful behavior.

A spontaneous order is an organic or emergent form of coordination that manifests itself in social institutions, some organizations and clusters of individual plans. Orders of this kind arise without the design and maintenance (oversight) of a social planner. Nevertheless, spontaneous orders are generated by individual agents who do plan and carry out actions within their sphere of activity. Social order emerges as individuals adjust their plans to each other and to the environment over time.

Spontaneous order theories come in different varieties. Some refer to order produced on markets, while others concern order produced in nonmarket settings. These theories can be purely positive (descriptive) or they can also be normative. When they are normative their normativity can be relative to the society as a whole or simply to particular subgroups.

At the most basic level, spontaneous order can refer simply to the welfareenhancing outcomes of competitive market processes operating within the "fixed" constraints of property, contract and tort law. This is best studied within the context of market entrepreneurship.

Bruce Benson (1989), in his path-breaking study of the spontaneous evolution of commercial law, shows how market interactions, based on basic property constraints, can give rise to commercial (contract) law without a lawgiver. The self-interested interactions of merchants lead them to develop and adhere to rules that increase their trade and hence overall social cooperation. These rules develop through a process of trial and error in which entrepreneurial alertness at a higher level - the level of rules of the game - doubtless plays an important role. Similarly, Stringham $(2002,2003)$ and Stringham and Boettke (2004) show that the self-interested interaction of participants in financial markets has generated useful regulations that govern the operation of these markets.

Peter Leeson $(2007,2009)$, in a number of studies of the organization of eighteenth-century pirate activity, shows how an outlaw subgroup of society 
developed maximizing (or "rational" in a limited sense) rules of governance without central direction. Outside of a market context, pirates converged on a set of rules whereby their ability to steal wealth from the rest of society was enhanced. This involved rules within the pirate society itself as well as rules governing its treatment of others. Within their society "democracy" was used; outside of it the use of brutality was constrained. This case is a good example of a spontaneous ordering process with "good" consequences within the subgroup and yet negative consequences for society as a whole. Pirates steal resources from the rest of society. The success of any such rogue subgroup weakens the possibilities of voluntary exchange and other forms of peaceful interaction.

Thomas McQuade and William Butos (2003; see also Butos and Koppl, 2003; Butos and McQuade, 2006) further develop the spontaneous order approach in the case of the organization of scientific research communities. Even where markets in the traditional sense may be missing, spontaneous that is, noncentrally directed - ordering processes are still present. They focus on the evolved nonmarket mechanism of publication-citation-reputation. Scientific knowledge is viewed as a "by-product" of the intentional activities of scientists to publish their results, get citations and enhance their reputations. Within this process competition among scientists tends to filter out inferior ideas. The resultant product ("science") is orderly in the sense that it tends to be reliable and codifiable. A set of procedures is put into place which acts as a filter to discriminate between rival claims. Furthermore, what comes out of the filter can be collected, integrated with other knowledge and transferred to other scientists.

These illustrations suggest the need for a more general theory of spontaneous order that would clarify the various conditions under which such ordering processes will take place. Specifically, it should also explore the role of markets and market prices, since it is clear that spontaneous order can develop without markets. From the welfare point of view the research discussed above leaves us with a puzzle: when do spontaneous orders produce an enhancement of social welfare and when a reduction in it, as in the case of pirate societies?

\section{Law and economics}

One of the most important areas of research in Austrian economics is the vibrant area of law and economics. Some of the contributions mentioned above in connection with spontaneous order and institutions could be included in this section. The field's uniquely Austrian features consist of attention to (1) the process of law and state intervention in markets; (2) the need for relatively stable law in a world of external change; (3) the influence of decentralized knowledge on the character and limits of law; and (4) the privatization of some of the basic functions of the state.

1. The most significant work on the processes generated by intervention since the classic analyses of Ludwig von Mises (1977), F.A. Hayek (1994) 
and Israel Kirzner (1985) can be found in Sanford Ikeda (1997, 2003, 2005) and in Mario Rizzo and Glen Whitman (2003). Ikeda's framework focuses on the deviation of the actual outcomes of intervention from the intended outcomes. This gap, based on an assumption of radical ignorance, generates price distortions, whether because the intervention takes the form of price regulations or because redistribution of wealth degrades incentives and thus individual responses to underlying economic data. These economic changes interact with largely, though not entirely, endogeneous changes in ideology to produce a tendency toward further policy intervention.

Rizzo and Whitman, on the other hand, begin from the largely philosophical and jurisprudential literature of "slippery slopes." They construct a general approach that emphasizes the role of changes in ideas, or more precisely, in the arguments that rationalize or justify legislative policies or judicial decisions. The mechanism by which these arguments change is a combination of the largely unanticipated consequences of decisions and the higher-level theories in which acceptable arguments are embedded.

Recently, Rizzo and Whitman (2009a; see also Whitman and Rizzo, 2007) have applied their slippery slope analysis in conjunction with many of the assumptions and findings of behavioral economics to demonstrate the expansive tendencies inherent in the supposedly moderate policies of new or "libertarian" paternalism.

The Rizzo-Whitman and Ikeda approaches seem largely compatible. Ikeda stresses more traditional economic processes, while Rizzo and Whitman stress the details of the intellectual changes that occur in the context of economic or other processes. In neither of these approaches is the "slippery slope" consequence of policies inevitable. They each describe tendencies that could be counterbalanced in specific cases, but which often have not been.

2. The classic work of Hayek $(1960,1973)$ on the rule of law simultaneously stresses the importance of stability in the legal framework and its adaptability to changing external circumstances. The solution to this paradox can be found in the level of abstraction of the relevant rules. For example, the abstract form of contract law can remain stable while the prices, conditions and content of exchanges vary at a point in time or over time. The consequences of abstraction in legal rules are examined in Whitman (2009). Whitman shows that an intermediate level of abstraction is optimal from the perspective of generating rules with predictable consequences.

From a slightly different perspective, Rizzo (1980a, 1980b, 1985) and Roy Cordato (2007) both criticize the cost-benefit framework in many conceptions of negligence law because it produces legal decisions that lack predictability to those for whom the particular law is relevant. Peter Lewin (1982) extends the critique to pollution externalities and social cost. The economic data upon which efficient legal decisions are to be made are often unavailable, complex or transient. This is especially true in a world characterized by radical uncertainty. Thus the so-called economic approach to tort law is defective on its own terms. Lack of predictability generates costs. In terms of 
the abstraction language of Whitman's analysis, the problem of the efficiency approach is that it enshrines a standard, rather than a set of specific rules, which is too abstract.

Similar criticisms of the so-called economic approach to property rights that derives from Ronald Coase and Harold Demsetz have been advanced by Walter Block. Block argues that the Coasean cost-benefit approach effectively abolishes property rights $(1977,1995,2000)$. This view is extended to the analysis of the recent US Supreme Court eminent domain case, Kelo v. City of New London (Block, 2006).

3. The decentralization of factual knowledge is a critically important factor limiting the feasibility of many forms of intervention. As in the earlier analysis of Mises (1977), the critiques discussed here begin from the announced goals of the interveners and do not challenge their worthiness. The approach is thus non-normative. It simply seeks to answer the question: can the policies achieve the goals that their advocates have set? Rizzo (2005) tackles this question in the case of moral paternalism: that is, the form of paternalism that coerces the individual in the interests of her moral betterment. Using the internal standards of three major ethical approaches - utilitarianism, natural law and Kantianism - Rizzo argues that the factual knowledge needed to determine just what the moral course of action is in concrete cases is not available to the paternalist. Rizzo (2005) also applies this kind of analysis to a form of economic paternalism based on behavioral economics. He argues that the factual knowledge that behavioral economics claims is relevant to the crafting of policies designed to improve the decisions of individuals exceeds what is known to the policy makers.

4. Most economic analysis proceeds on the assumption that the state exercises at least its minimum functions: that is, provision of protection, enforcement of property rights and contracts, and the adjudication of disputes. Nevertheless some economists in the broad Austrian and spontaneous order tradition have argued that privatization of at least some of these functions is feasible and desirable. Bryan Caplan and Edward Stringham (2008) have compared the private and public adjudication of disputes. They find that private adjudication is more efficient in areas of commercial disputes, and more generally in those areas where prior relationships exist among the parties. They also speculate on a broader use of private adjudication. In a related area of public choice economics, Powell and Stringham (2009) survey a surprisingly large extant literature on the economics of a stateless society.

\section{Bibliography}

Baetjer, H. 2000. Capital as embodied knowledge: some implications for the theory of economic growth. Review of Austrian Economics 13, 147-74.

Benson, B. 1989. The spontaneous evolution of commercial law. Southern Economic Journal 55, 644-61.

Block, W. 1977. Coase and Demsetz on private property rights. Journal of Libertarian Studies 1, 111-15. 
Block, W. 1988. Fractional reserve banking. In Man, Economy and Liberty: Essays in Honor of Murray H. Rothbard, ed. W. Block and L. Rockwell. Auburn Ala: Mises Institute, pp. 24-31.

Block, W. 1995. Ethics, efficiency, Coasian property rights, and psychic income: a reply to Demsetz. Review of Austrian Economics 8, 61-125.

Block, W. 2000. Private-property rights, erroneous interpretations, morality, and economics: reply to Demsetz. Quarterly Journal of Austrian Economics 3, 63-78.

Block, W. 2006. Coase and Kelo: ominous parallels and reply to Lott on Rothbard on Coase. Whittier Law Review 27, 997-1022.

Boettke, P. J. and Coyne, C. 2002. Entrepreneurship and development: cause or consequence? Advances in Austrian Economics 6, 67-88.

Boettke, P. J. and Coyne, C. 2009. Context matters: institutions and entrepreneurship. Foundations and Trends in Entrepreneurship 5, 135-209.

Boettke, P.J., Coyne, C.J. and Leeson, P.T. 2008. Institutional stickiness and the new development economics. American Journal of Economics and Sociology 67, 331-58.

Butos, W.N. and Koppl, R. 2003. Science as a spontaneous order. In The Evolution of Scientific Knowledge, ed. H.S. Jensen, L.M. Richter and M.T. Vendelø. Northampton, Mass.: Edward Elgar, pp. 164-88.

Butos, W.N. and McQuade, T.J. 2006. Government and science: a dangerous liaison? Independent Review 11, 177-208.

Caplan, B. and Stringham, E.P. 2008. Privatizing the adjudication of disputes. Theoretical Inquiries in Law 9, Article 8. Available at: http://ezproxy.library.nyu. edu:4274/til/default/vo19/iss2/art8.

Chamlee-Wright, E. 2008. The structure of social capital: an Austrian perspective on its nature and development. Review of Political Economy 20, 41-58.

Chamlee-Wright, E. and Myers, J.A. 2008. Discovery and social learning in nonpriced environments: an Austrian view of social network theory. Review of Austrian Economics 21, 151-66.

Choi, Y.B. 1993. Paradigms and Conventions: Uncertainty, Decision Making, and Entrepreneurship. Ann Arbor, Mich.: University of Michigan Press.

Choi, Y.B. 1999. Conventions and learning: a perspective on the market process. In Economic Organisation and Economic Knowledge, ed. S.C. Dow and P. Earl. London: Edward Elgar, pp. 57-75.

Cordato, R. 2007. Efficiency and Externalities in an Open-Ended Universe. Auburn, Ala.: Ludwig von Mises Institute, 1992.

Cowan, R. and Rizzo, M.J. 1996. The genetic-causal tradition and modern economic theory. Kyklos 49, 273-317.

Cowen, T. 1998. Risk and Business Cycles: New and Old Austrian Perspectives. London: Routledge.

Dowd, K. 1996. Laissez-Faire Banking. London: Routledge.

Dowd, K. 2000. Money and the Market: Essays on Free Banking. London and New York: Routledge.

Ebeling, R.M. 2007. Austrian economics and the political economy of freedom. New Perspectives on Political Economy 3, 87-104. Available at: http://pcpe.libinst.cz/ nppe/3_1/nppe3_1.pdf.

Endres, A.M. and Harper, D.A. 2008. Capital as a Layer Cake: Menger, Lachmann and the Nature of Capital. Unpublished manuscript, New York University.

Foss, K. and Foss, N.J. 2006. The limits to designed orders: authority under 'distributed knowledge' conditions. Review of Austrian Economics 19, 261-74. 
Foss, K. and Foss, N.J. 2007. The entrepreneurial organization of heterogeneous capital. Journal of Management Studies 44, 1165-86.

Foss, K., Foss, N.J. and Klein, P.G. 2007. Original and derived judgment: an entrepreneurial theory of economic organization. Organization Studies 28, 1-20.

Garrison, R. 2001. Time and Money: The Macroeconomics of Capital Structure. London: Routledge.

Garrison, R. 2004. Overconsumption and forced saving in the Mises-Hayek theory of the business cycle. History of Political Economy 36, 323-49.

Harper, D.A. 1998. Institutional conditions for entrepreneurship. Advances in Austrian Economics 5, 241-75.

Harper, D.A. 2003. Foundations of Entrepreneurship and Economic Development. London: Routledge.

Harper, D.A. 2008a. A bioeconomic study of numeracy and economic calculation. Journal of Bioeconomics 10, 101-26.

Harper, D.A. 2008b. Towards a theory of entrepreneurial teams. Journal of Business Venturing 23, 613-26.

Harper, D.A. 2010. Numbers as a cognitive and social technology: on the nature of conventional number sequences used in economic systems. Journal of Institutional Economics 6, 167-90.

Hayek, F.A. 1948. The use of knowledge in society. In Individualism and Economic Order. Chicago: University of Chicago Press.

Hayek, F.A. 1960. The Constitution of Liberty. Chicago: University of Chicago Press.

Hayek, F.A. 1967. The results of human action but not of human design. In Studies in Philosophy, Politics and Economics. London: Routledge \& Kegan Paul.

Hayek, F.A. 1973. Law, Legislation and Liberty, Vol. 1: Rules and Order. Chicago: University of Chicago Press.

Hayek, F.A. 1944. The Road to Serfdom. Chicago: University of Chicago Press, 1994.

Holcombe, R.G. 2007. Entrepreneurship and Economic Progress. London: Routledge.

Hoppe, H.H. 1994. How is fiat money possible? or, the devolution of money and credit. Review of Austrian Economics 7, 49-74.

Horwitz, S. 2000. Microfoundations and Macroeconomics: An Austrian Perspective. London: Routledge.

Huerta de Soto, J. 1995. A critical analysis of central banks and fractional-reserve free banking from the Austrian perspective. Review of Austrian Economics 8, 25-38.

Huerta de Soto, J. 2006. Money, Bank Credit, and Economic Cycles, trans. M.A. Stroup, Auburn, Ala.: Ludwig von Mises Institute.

Ikeda, S. 1997. Dynamics of the Mixed Economy: Toward a Theory of Interventionism. London: Routledge.

Ikeda, S. 2003. How compatible are public choice and Austrian political economy? Review of Austrian Economics 16, 63-75.

Ikeda, S. 2005. The dynamics of intervention: regulation and redistribution in the mixed economy. Advances in Austrian Economics 8, 21-57.

Jakee, K. and Spong, H. 2003. Praxeology, entrepreneurship and the market process: a review of Kirzner's contribution. Journal of the History of Economic Thought 25, 461-86.

Kirzner, I.M. 1973. Competition and Entrepreneurship. Chicago: University of Chicago Press.

Kirzner, I.M. 1979. Perception, Opportunity, and Profit: Studies in the Theory of Entrepreneurship. Chicago: University of Chicago Press. 
Kirzner, I.M. 1982. Uncertainty, discovery, and human action: a study of the entrepreneurial profile in the Misesian system. In Method, Process, and Austrian Economics. Lexington, Ky.: Lexington Books.

Kirzner, I.M. 1985. The perils of regulation: a market process approach. In Discovery and the Capitalist Process. Chicago: University of Chicago Press.

Kirzner, I.M. 1992a. Prices, the communication of knowledge and the discovery process. In The Meaning of Market Process. London: Routledge.

Kirzner, I.M. 1992b. Knowledge problems and their solutions: some relevant distinctions. In The Meaning of Market Process. London: Routledge.

Kirzner, I.M. 1997. Entrepreneurial discovery and the competitive market process: an Austrian approach. Journal of Economic Literature 35, 60-85.

Klein, D.B. 1997. Convention, social order, and the two coordinations. Constitutional Political Economy 8, 319-35.

Klein, D.B. and Briggeman, J. 2009. Israel Kirzner on coordination and discovery. Journal of Private Enterprise 25, 1-53.

Klein, P.G. 2008. Opportunity discovery, entrepreneurial action, and economic organization. Strategic Entrepreneurship Journal 2, 175-90.

Knight, F.H. 1971. Risk, Uncertainty, and Profit. Chicago: University of Chicago Press.

Koppl, R. 2002. Big Players and the Economic Theory of Expectations. Hampshire and New York: Palgrave Macmillan.

Koppl, R. and Mramor, D. 2003. Big players in Slovenia. Review of Austrian Economics 16, 253-69.

Koppl, R. and Yeager, L.B. 1996. Big players and herding in asset markets: the case of the Russian ruble. Explorations in Economic History 33, 367-83.

Lachmann, L.M. 1956. Capital and Its Structure. London: G. Bell \& Sons.

Leeson, P. 2007. An-arrgh-chy: the law and economics of pirate organization. Journal of Political Economy 115, 1049-94.

Leeson, P.T. 2009. The Invisible Hook: The Hidden Economics of Pirates. Princeton, NJ: Princeton University Press.

Lewin, P. 1982. Pollution externalities: social cost and strict liability. Cato Journal 2, 205-29.

Lewin, P. 1999. Capital in Disequilibrium: The Role of Capital in a Changing World. London: Routledge.

Lewis, P. and Chamlee-Wright, E. 2008. Social embeddedness, social capital and the market process: an introduction to the Special Issue on Austrian Economics, Economic Sociology and Social Capital. Review of Austrian Economic 21, 107-18.

McQuade, T.J. and Butos, W.N. 2003. Order-dependent knowledge and the economics of science. Review of Austrian Economics 16, 133-52.

Mises, L. von. 1912. The Theory of Money and Credit. New Haven, Conn.: Yale University Press, 1953.

Mises, L. von. 1929. A Critique of Interventionism, trans. H.F. Sennhollz, New Rochelle, N.Y.: Arlington House, 1977.

O'Driscoll, G.P. Jr. and Rizzo, M.J. 1996. The Economics of Time and Ignorance. London: Routledge.

Powell, B.W. and Stringham, E.P. 2009. Public choice and the economic analysis of anarchy: a survey. Public Choice 140, 503-38. 
Rizzo, M.J. 1980a. Law amid flux: the economics of negligence and strict liability in tort. Journal of Legal Studies 9, 291-318.

Rizzo, M.J. 1980b. The mirage of efficiency. Hofstra Law Review 8, 641-58.

Rizzo, M.J. 1982. Mises and Lakatos: a reformulation of Austrian methodology. In Method, Process, and Austrian Economics, ed. I. Kirzner. Lexington, Ky.: Lexington Books.

Rizzo, M.J. 1985. Rules versus cost-benefit analysis in the common law. Cato Journal 4, 865-84.

Rizzo, M.J. 1990. Hayek's four tendencies towards equilibrium. Cultural Dynamics 3, $12-31$.

Rizzo, M.J. 1996. Introduction: time and ignorance after ten years. In The Economics of Time and Ignorance, ed. G.P. O’Driscoll, Jr and M.J. Rizzo. London: Routledge.

Rizzo, M.J. 2000. Real time and relative indeterminacy in economic theory. In Time in Contemporary Intellectual Thought, ed. P. Baert. Amsterdam: Elsevier, pp. 171-88.

Rizzo, M.J. 2005. The problem of moral dirigisme: a new argument against moralistic legislation. NYU Journal of Law and Liberty 1, 790-844.

Rizzo, M.J. and Whitman, D.G. 2003. The camel's nose is in the tent: rules, theories, and slippery slopes. UCLA Law Review 51, 539-92.

Rizzo, M.J. and Whitman, D.G. 2009a. Little brother is watching you: new paternalism on the slippery slopes. Arizona Law Review 51, 685-739.

Rizzo, M.J. and Whitman, D.G. 2009b. The knowledge problem of new paternalism. Brigham Young University Law Review 2009, 905-68.

Rothbard, M.N. 1983. The Mystery of Banking. Auburn, Ala.: Ludwig von Mises Institute.

Salerno, J.T. 1993. Mises and Hayek dehomogenized. Review of Austrian Economics $6,113-46$.

Salerno, J.T. 2003. An Austrian taxonomy of deflation - with applications to the U.S. Quarterly Journal of Austrian Economics 6, 81-109.

Salerno, J. T. 1994. Reply to Leland B. Yeager on "Mises and Hayek on Calculation and Knowledge." Review of Austrian Economics 7, 111-25.

Salerno, J.T. 2008. The entrepreneur: real and imagined. Quarterly Journal of Austrian Economics 11, 188-207.

Sautet, F.E. 2000. An Entrepreneurial Theory of the Firm. London: Routledge.

Schumpeter, J.A. 1911. Theory of Economic Development. Cambridge, Mass.: Harvard University Press, 1934.

Sechrest, L. 1993. Free Banking: Theory, History, and a Laissez-Faire Model. Westport, Conn.: Quorum.

Selgin, G.A. and White, L.H. 1994. How would the invisible hand handle money? Journal of Economic Literature 32, 1718-49.

Shane, S. 2000. Prior knowledge and the discovery of entrepreneurial opportunities. Organization Science 11, 448-69.

Stringham, E. 2002. The emergence of the London Stock Exchange as a self- policing club. Journal of Private Enterprise 17, 1-19.

Stringham, E. 2003. The extralegal development of securities trading in seventeenthcentury Amsterdam. Quarterly Review of Economics and Finance 43, 321-44.

Stringham, E. and Boettke, P. J. 2004. Brokers, bureaucrats and the emergence of financial markets. Managerial Finance 30, 57-71. 
Wagner, R. 2005. Austrian Cycle Theory and the prospect of a coordinationist macroeconomics. In Modern Applications of Austrian Thought, ed. J.G. Backhaus. London and New York: Routledge, pp. 77-92.

Wagner, R. 2007. Value and exchange: two windows for economic theorizing. Review of Austrian Economics 20, 57-68.

Wagner, R. 2010. Mind, Society, and Human Action: Time and Knowledge in Social Economy. London and New York: Routledge.

Whitman, D.G. 2009. The rules of abstraction. Review of Austrian Economics 22, 21-42.

Whitman, D.G. and Rizzo, M.J. 2007. Paternalist slopes. NYU Journal of Law and Liberty 2, 411-43.

Williamson, O.E. 2000. The new institutional economics: taking stock, looking ahead. Journal of Economic Literature 38, 595-613.

\section{How to cite this article}

Rizzo, Mario J. "Austrian economics: recent work." The New Palgrave Dictionary of Economics. Online Edition. Eds. Steven N. Durlauf and Lawrence E. Blume. Palgrave Macmillan, 2009. The New Palgrave Dictionary of Economics Online. Palgrave Macmillan. 26 November 2011 http://www.dictionaryofeconomics.com/ article?id=pde2009_A000258 doi:10.1057/9780230226203.1915. 